\title{
Privatisation in Botswana: A Case of Firsts Not Happening First?
}

\author{
Emmanuel Botlhale \\ Department of Political and Administrative Studies, University of Botswana \\ Private Bag UB 00705, Gaborone, Botswana
}

Tel: 267-7211-1321 E-mail: botlhale@ mopipi.ub.bw

\author{
Received: May 11, $2011 \quad$ Accepted: November 24, 2011 Published: March 1, 2012 \\ doi:10.5296/rae.v4i1.657 URL: http://dx.doi.org/10.5296/rae.v4i1.657
}

\begin{abstract}
The late 1980s and early 1990s were characterised by unprecedented waves of privatisation in the world. Like other developing economies, Botswana jumped into the bandwagon and laid the legal framework for privatisation by way of promulgating a Privatisation Policy for Botswana in 2000. It is notable that despite the promulgation of the Policy, privatisation will only commence with the privatisation of the National Development Bank (NDB) in late 2011. This paper, relying on a variety sources; for example, newspaper accounts, personal interviews etc traces the privatisation process beginning with the appointment of the Privatisation Task Force in 1997, the passage of the Privatisation Policy for Botswana in 2000 and right up to the aborted privatisation of Air Botswana and the recent decision to privatise the NDB. Largely drawing from the Air Botswana saga, the paper argues that key firsts, being the delineation of an institutional-legal framework and public education on privatisation, either did not happen first or sloppily happened. As it is, Botswana has crossed the Rubicon, therefore, there is no going back on privatisation. Hence, as the government goes ahead with the privatisation of NDB, and the Botswana Telecommunications Corporation thereafter, there is a need to either do first things firstly or do them correctly so that the privatisation project can be successfully delivered. Principally, the powers of the both the executive and legislative arms of government must be delineated in regard to privatisation and public education must be an ongoing exercise to ensure a buy-in.
\end{abstract}

Keywords: Privatisation, Botswana, Privatisation Policy for Botswana, Public Enterprise Evaluation and Privatisation Agency (PEEPA) 


\section{Introduction}

Privatisation has been a public policy since the incipience of time as next illustrated. In ancient Greece, governments are said to have contracted out the delivery of goods and services to the market (Means, 2001). Similarly, traces of privatisation are found in the Roman Republic, where the state contracted out some services such as tax collection and construction to private individuals (Sobel, 1999), and during the Ch'in dynasty in the 1500s (Means, 2001). In pre-modern times, the virtues of private ownership over public ownership were extolled by Adam Smith in 1776 in his celebrated classic, Wealth of Nations (Smith, 1776). Thus, privatisation has been a common public policy throughout the years, gaining momentum after World War II and spurred on by the creation of the Bretton Woods institutions, the World Bank and International Monetary Fund, which advocate for the scaling back of state frontiers. However, it became a predominant economic policy during the period of Reagonomics and Thatcherite economics in the 1980s. The ascendancy of Ronald Reagan and Margaret Thatcher to the presidency and premiership of the US and UK respectively, with their advocacy for free markets, re-energised the advocacy for privatisation in the developed world. Privatisation, chiefly epitomised by reinvention of government proponents such as Osborne and Gaebler (1992), Gore (1993) and Osborne and Plastrik (1997), was elevated to the cult status that it enjoys today. The developing world, more especially Africa, was not spared the onslaught of privatisation as it later diffused to it. Due to bloated and inefficient public sectors, it found fertile ground in Africa. Although it is manifest that privatisation has had the least impact in Africa, as sufficiently instanced by the Zambian experience (IRIN, 2003; Kangwa, 2001), so far, African governments, under pressure from either the World Bank (WB) or International Monetary Fund (IMF), are religiously scaling back the frontiers of the state in favour of laissez-faire markets.

It is noteworthy, however, that unlike a majority of African countries; for example Zambia, Mozambique, Tanzania, Nigeria and Central African Republic (see Cleary, 1989), neither the WB nor IMF pressured Botswana into reducing the state, rather, hers is a self-imposed privatisation exercise called Public Private Partnership (PPP). The Task Force on Privatisation put it concretely when it stated that "by contrast, privatisation in Botswana is not being adopted as a solution to an immediate financial, economic or political crisis (ROB, 1997:2)." As a matter of fact, the overarching objective was to enhance efficiency in both private and public sectors and diversify the economy away from diamonds and the government (ibid). Despite failing to privatise Air Botswana (AB) in mid 2007 because of a parliamentary motion that sought to interdict government from concluding negotiation deals with Airlink, the government has decided to proceed with the exercise as instanced by its decision to privatise the National Development Bank (NDB) in March 2011 and Botswana Telecommunications Corporation (BTC) at a later stage. Importantly, the NDB is yet to be privatised, thus, it is possible to have an AB-style imbroglio. Hence, a few firsts, being, the delineation of an institutional-legal framework and public education on privatisation need to be attended to so that the privatisation of the NDB and BTC can be fruitfully implemented.

Since privatisation is a policy that Botswana cannot repudiate and given the lack of research in the area except Mothusi and Dipholo (2008), the case for exploratory articles on 
privatisation cannot be oversold. Such papers will discuss factors that have so far led to the faltering of privatisation in Botswana. In this connection, this paper proceeds as follows; it defines privatisation; discusses the Privatisation Policy for Botswana; discusses initial reactions to privatisation and the aborted privatisation of Air Botswana; lessons learned from the aborted privatisation of Air Botswana; proposes the way forward and concludes.

\section{Definition}

Privatisation is a fluid concept (see Kosar, 2006; Weizsacker et al., 2005) and, thus, it does not readily lend itself to definition. In this regard, many definitions have been proffered in a bid to give the term some definitional legitimacy (see Savas, 1987; Starr, 1988; Kahn and Kamerman, 1989 and Ress and Love, 1995). Out of these many definitions, the paper employs Savas' (1997:1) definition; "as a process, privatisation denotes reducing the roles of government, while increasing those of the private sector, in activities or asset ownership." On the other hand, the Privatisation Policy for Botswana (2000) defines it thusly; “...privatisation encompasses all the measures and policies aimed at strengthening the role of the private sector in the economy (ROB, 2000:7)." A word of warning is in order because as much as there is a variety of attempts to define the term, controversy everlastingly dogs it (see Starr, 1988). The allure of privatisation means that there are many reasons that have been advanced in its support. Overall, the objectives of privatisation programmes are: (i) to achieve higher allocative and productive efficiency; ii) to strengthen the role of the private sector in the economy; (iii) to improve the public sector's financial health; and (iv) to free resources for allocation in other in other important areas of government activity (Sheshinski and López-Calva, 2003).

Privatisation is effected through many forms; e.g., corporatisation, sales to the public, private sales and insolvency and sales of assets (Graham, 2003), and it is generally believed to be beneficial. In this connection, Savas (1987:228), one of its foremost proponents, holds that;

P]rivatization is the key to both limited and better government: limited in size, scope, and power relative to society's other institutions; and better in that society's needs are satisfied more efficiently, effectively, and equitably. Privatization is both a means and an end. For pragmatists who want better government and for populists who seek a better society, privatization is a means toward those ends.

To counterbalance the foregoing, there are dissenters; e.g., Weizsacker et al. (2005), Becker (1988); Willner (2003) and Stiglitz (2002). Weizsacker et al. (2005:4) hold that a balance must be struck between the private sector and public domain and warn that "the recent and continuing swing towards privatisation is in danger of becoming too much of a good thing" and further that "it may carry consequences that outweigh the undeniable benefits of many forms of privatisation." Similarly, Becker (1988:95) argues that privatisation may adversely affect women and minorities as they readily find jobs in the public sector.

Despite the costs of privatisation, it is on the march and has been adopted by almost every country in the world. Rather than asking, 'should we privatise?', the question to ask is, 'how should we privatise?' In this connection, Botswana finds herself in the same situation; she 
cannot question the virtues of privatisation but, rather, she has to worry about how same can be best implemented. Thus, since resources are limited, society must make choices regarding the three basic questions: (i) what to produce; (ii) how to produce it; and (iii) for whom to produce (see Meggison and Netter, 2003). Similarly, choices must be made regarding private and public provision (see Madumbi, 2003). This choice, as observed by Edmund Burke, an Anglo-Irish statesman, who once said that "one of the finest problems in legislation is [namely] what the State ought to take upon itself to direct by the public wisdom, and what ought to leave, with as little interference as possible, to individual discretion (quoted in Middleton, 1966:41)", is no easy one, hence, incessant battles over private/public provision.

\section{The case of Botswana}

Given the economic dire straits that Botswana found herself in at independence as a result of the British government's deliberate decision to minimally invest in the economy (see Tsie, 1998; Edge, 1998; Acemoglu et al., 2001), it was prudential that massive public investments be undertaken to jump-start the economy. In the main, this took the establishment of State-Owned Enterprises (SOEs) and investment arms such as Botswana Development Corporation (BDC). Notably, public investments that characterised the new developmental state were possible due to mineral proceeds that saw it posting exceptional growth rates. However, the late 1990s saw a slowdown in diamond revenues, the backbone of the economy, and the withdrawal of donor support by, amongst others, the Swedish International Development Agency (SIDA) and Norwegian Agency for Development (NORAD). These new economic realities actuated a major rethink as the government started searching for ways of diversifying the economy away from the state. This change in policy was most instanced by the Budget Speech presented to Parliament on 12 February 1996 by then Minister of Finance and Development Planning, Festus Mogae (Mogae, 1996). In essence, Mogae threatened to close the Public Debt Service Fund financial tap and accordingly exhorted SOEs to improve their efficiency. True to his word, four years later, privatisation was legislated into existence.

Subsequent to deliberation and consultation, the government issued Government Paper No. 1 of 2000 to actualise privatisation. The project was to commence during the 2001/2002 fiscal year but, actually, commenced during the 2007/08 fiscal period. Botswana does not have to re-invent the wheel as far as the rationale for privatisation is concerned. In conformity with worldwide trends, two of the overarching reasons behind privatisation are that it will engender efficiency in privatised entities and, more importantly, relieve budgetary pressures on the government by loss-making SOEs. As per the Privatisation Policy for Botswana, the following principles advise privatisation:

(i) Privatisation will be conducted for the benefit of all, not for the privileged few;

(ii) Privatisation should make the country's utilities and industries more efficient and competitive;

(iii) The privatisation of major assets will be conducted in a way that will stimulate the development of local financial and capital markets; and 
(iv) When privatisation occurs, measures will be taken to safeguard employee interests (ROB, 2000:7).

Furthermore, the Policy identifies critical privatisation success factors; some of which are: a demonstrated political commitment to the implementation of privatisation, an enabling legal and institutional framework and enunciation of potential benefits and costs and full transparency in the privatisation exercise. In essence, principles that advise privatisation are: ensuring transparency and equity in the implementation of the privatisation process; privatisation for the benefit of all and not a few; and ensuring active citizen participation in the process promoted through constant communication with all stakeholders (PEEPA, 2009).

There are a number of SOEs in Botswana and some of the key candidates for privatisation are National Development Bank, Botswana Telecommunications Corporation and Air Botswana. Among government-provided services, cleaning, security, garbage-collection and landscaping have been identified as possible candidates and it is noteworthy that some municipalities have already taken steps in this direction (see Matambo, 2011). To illustrate, in early 2000, the Gaborone City Council privatised garbage collection (Mmegi, 2005).

To implement privatisation, the government established the Public Enterprise Evaluation and Privatisation Agency (PEEPA). PEEPA is an autonomous body that was established in 2001 in terms of the Privatisation Policy for Botswana [Government Paper No. 1 of 2000] (PEEPA, 2009). Its mandate is "to advise on and oversee all aspects of the implementation of commercialisation and privatisation on behalf of Government as well as to monitor the performance of Public Entities with a view to assess whether they are meeting their objectives and targets (ibid: paragraph 1)." In addition, PEEPA is also mandated to advise the government on the appointment of Directors of Public Enterprises and monitor the performance of those Directors and Boards (ibid). Overall, the brief of PEEPA entails the following: (i) identifying candidates for privatisation [or commercialisation/corporatisation] and deciding on the appropriate course of action; (ii) preparing a national privatisation master scheme; and (iii) mounting education campaigns on privatisation (ibid).

Following its establishment, PEEPA carried out a major review of the operations and activities of SOEs and the exercise also included the examination of opportunities for private sector participation in activities of central government departments and Local Authorities (PEEPA, 2009). The end result of the review was the development a Privatisation Master Plan (PMP) in 2005. Overall, the PMP "outlines strategies, principles and practices to be followed to achieve privatisation objectives and the regulatory, institutional and legal changes that are required to ensure effective implementation of the Privatisation Policy (ibid)." In this regard, the Plan's objectives are:

(i) Promoting competition, improving efficiency and increasing productivity of enterprises;

(i) Accelerating the rate of economic growth by stimulating entrepreneurship and investment;

(iii) Increasing direct citizen participation in the ownership of national assets;

(iv) Withdrawing from commercial activities which no longer need public sector involvement; 
(v) Reducing the size of the public sector; and

(vi) Broadening and deepening the capital market (ibid).

\section{Initial reactions to privatisation}

Inevitably, every major policy reform elicits responses from many quarters as soon as it enters the public domain. In this regard, no sooner had the Privatisation Policy for Botswana been legislated into existence than various stakeholders registered their views. Privatisation affects a number of actors and these include: (i) government; (ii) employees; (iii) customers; (iv) public; (v) civil society and; (vi) labour unions. In this connection, we focus on a few stakeholders to illuminate initial reactions to privatisation. Predictably, labour unions led the onslaught on privatisation. Overall, they were worried about potential job losses as adequately exemplified by the case of Zambia (IRIN, 2003). In this regard, the Botswana Confederation of Commerce, Industry and Manpower (BOCCIM) was similarly persuaded but, nonetheless, cautioned that job losses were justified in "cases where government is withdrawing from socially-oriented activities which are not commercially viable as a result of the privatisation programme (BOCCIM, 1996:30)."

In the same vein, Non-Governmental Organisations (NGOs) expressed their opposition to privatisation. To illustrate, at a conference organised by the Friedrich Ebert Foundation for the Botswana Council of Non-Governmental Organisations (BOCONGO), NGOs expressed their opposition to privatisation. Predictably, then PEEPA chief, Joshua Galeforolwe, tried in vain to sell privatisation to the NGOs but they refused to buy. For example, Emmanuel George of Botswana Network of AIDS Services Organisation (BONASO) cautioned PEEPA against duplicating the Zambian model of privatisation. He put it concretely saying, "beneficiaries of privatisation should not be put first but the victims of privatisation" and that "in Zambia, we started with a privatisation programme but ended up with a poverty alleviation programme (Molaodi, 2004:1). In a similar vein, the founder and Director of the South African-based African Institute of Corporate Citizenship, Mokgethi Moshoeshoe, was less enthused by privatisation and said, "I do not mean to be anti-privatisation. But you have failed dismally to convince me that privatisation is the way to go (ibid)."

Thus, it is noteworthy that the Privatisation Policy for Botswana asserts that the success of privatisation is dependent upon the explanation of potential benefits and costs to all stakeholders. The foregoing is a good policy pronouncement but it is deducible from the above illustrations there is a divergence between intent and outcome. To further illustrate the divergence, one then labour union official told the author that "we are opposed to privatisation because we neither understand nor trust the process (Interview, 28 October 2004)." Thus, it was apparent that most of the opposition to privatisation is borne out of ignorance. Instructively, when the Policy was adopted, some villagers asserted that it was "a Gaborone thing" [Gaborone is the capital city] and this fed into their suspicions and resultant opposition to privatisation. For example, then Assistant Minister of Finance and Development Planning, Slumber Tsogwane, had to allay Moshupa residents' fears about the ill-effects of privatisation in a kgotla (public) meeting in June 2004 (BOPA, 2004). 
At the same time, PEEPA read the mood of labour unions and similar-minded stakeholders and did its best to ally their fears. To illustrate, it accepted an invitation to then Botswana Federation of Secondary School Teachers (BOFESETE) conference in Lobatse in late August 2004. BOFESETE had, amongst others, invited politicians and fellow trade unions and civil society to its annual conference under the theme, 'Will Privatisation Empower Teachers (PEEPA, 2004). In essence, BOFESETE wanted to explore ways in which it could position itself with regard to privatisation. Overall, while it was expressed a consensus position that privatisation was not necessarily a bad public policy, the need for caution was, nonetheless, proffered. In this regard, the Botswana Congress Party's (BCP) Dumelang Saleshando stated that privatisation should be used to empower Batswana, not to disempower them (ibid). At the same time, PEEPA's then Chief Executive Officer, Joshua Galeforolwe, assured the naysayers that accommodating labour concerns, among other stakeholders, "was a key element of the implementation of a successful privatisation programme (ibid)."

Thus, the above are illustrations of events that followed the adoption of the Privatisation Policy for Botswana in 2000. Thus, overall, there was suspicion and resultant opposition which were largely borne out of insufficient knowledge of privatisation. In the subsequent and despite oppostion, in mid 2006, the government started preparing the ground to effect privatisation by privatising Air Botswana (AB). As would be demonstrated by the abortive exercise, there lacked a clearly delimited legal-institutional framework in respect to role divisions between the Cabinet and Parliament in respect to privatisation.

\section{The Aborted Privatisation of Air Botswana}

Air Botswana was earmarked as the guinea pig of privatisation in Botswana and, in this regard, in mid December 2006, the Cabinet week gave the Ministry of Works and Transport the go-ahead to begin negotiations with the South Africa-based regional airline SA Airlink on the privatisation of Air Botswana (Mmegi, 2006). This was subsequent to the Public Procurement and Asset Disposal Board's (PPADB), the government authority responsible for procurement and disposal probity, endorsement of SA Airlink (Pty) Ltd as the preferred bidder for the privatisation of Air Botswana [AB] (ibid). In this connection, the objectives of AB's privatisation were, amongst other things, to ensure continuity of air transport and the development of viable, safe and efficient air services (ibid).

While it appeared that all things were in place for the privatisation of $A B$, some suspected that the exercise was being conducted in a manner that was contrary to the Air Botswana Transaction Act "which provides for the provision of Air Botswana as a public company under the Companies Act; for its continued existence as if it had been incorporated under that Act and for matters incidental thereto (Motlogelwa, 2007:1)'. Thus, then Member of Parliament for Francistown South, Khumongwana Maoto, opposed the on-going negotiations concerning the privatisation of $\mathrm{AB}$ and moved a motion in parliament that same be suspended forthwith (Piet, 2009). He argued that the current privatisation negotiations did not conform to the following conditions:

(1) The letter and/or spirit of the Air Botswana Transition Act; and 
(2) The letter and/or spirit of the Civil Aviation Regulation Reform Act because the on-going privatization requires or entails the closure or liquidation of the existing company while the above enactments envisage the privatization of the existing company as a going concern (Motlogelwa, 2007:1).

Overall, Maoto's motion enjoyed support across the political divide and there was concern that Botswana would lose a national airline, a source of pride, and job losses due to liquidation of $\mathrm{AB}$. In addition, and notably, Parliament argued that as the custodian of public assets, $\mathrm{AB}$ being one, it had a stake in the matter for it had to represent the interests of the citizens. Thus, it demanded a place at the table of negotiations but the Cabinet refused and it sought legal advice from the Attorney General, Atalia Molokomme. She asserted that;

As a general principle, unlike Acts, parliamentary resolutions are not binding on the executive, but are binding on parliament itself. However, Parliament also has the power to table motions aimed at influencing the policy directions of the executive. In this context, the current Air Botswana negotiations should be seen as a process, which falls squarely within the preserve of the executive function, and cannot be suspended simply by a Parliamentary motion to that effect. However, the outcome should not be contrary to the law, in particular the Air Botswana (Transition) Act (Cap. 74:09) and the Civil Aviation Regulation (Reform) Act (Cap. 71:03) (The Voice, 2007:1).

At the same time, then Minister for Works and Transport, Lesego Motsumi, said this about the same matter:

I have been instructed by Cabinet to carry out negotiations with SA Airlink. I will continue doing that until Cabinet instructs me otherwise, which at the moment it has not done. Parliament has a legitimate right to discuss and agree on any matter of public concern. But this matter has to be understood in the context that we are currently in the middle of negotiations, whose conclusions-positive or negative- has to be delivered to cabinet at some point. If these negotiations were to be suspended what will I report to Cabinet at the end of the day (Motlogelwa, 2007:1).

On a contrary vein, Gladys Kokorwe, then Deputy Speaker, asserted the supremacy of parliament when she said, "the Executive has to get used to the idea that these are modern times and the era of Parliament acting as a rubber stamping institution for the Executive is over... (ibid)." Connectedly, then Parliamentary Counsel, Lizo Ngcongco, held that Parliament motions were binding on the Executive because Parliament is supreme to the latter. The stalemate became a field day for legal pundits who faulted Molokome's legal opinion (see Bayford, 2007; 'Molokomme is wrong' and Lekalake, 2007; 'The Attorney General is wrong; a second legal opinion') and the opposition also weighed in on same; e.g., the Botswana Congress Party threatened to take the government to court (Mooketsi, 2007). In this connection, Dick Bayford, a private attorney, promised to lead a legal team to challenge the Executive's insistence to privatise AB despite the adoption of Maoto's motion (Modise, 2007). Finally, the government capitulated and AB's privatisation was stopped. 
At about the same time (i.e., mid 2007), another parastatal, the Botswana Telecommunications Corporation (BTC), was reported to be ready for privatisation (Baputaki 2007). BTC is yet to be privatised and in December 2009, then Assistant Minister of Finance and Development Planning, Charles Tibone, told the nation that the National Development Bank (NDB) was ripe for privatisation (Direng, 2009). He, thus, held that the NDB "should be allowed to privatise because it has shown over the years that it has grown and is ready to become an independent organisation (ibid:1)." Previously, in June 2009, the government held a stakeholders consultative conference on the privatisation of the NDB (Mosinyi, 2009). At the conference, then Assistant Minister of Finance and Development Planning, Keletso Rakhudu, said that the government "will benchmark on the failures of its initially botched plans to privatise Air Botswana and consult extensively while it considers privatising another public entity, the National Development Bank (ibid)." He further advised the attendees that privatisation was a complex process and that to rightly and advantageously implement it, all opinions had to be taken aboard. Ending, he told them about the inescapability of privatisation the world over by saying that "the issue these days is no longer whether or not to privatise, but how privatisation programmes can best be designed and implemented to achieve maximum benefits for the country (ibid)."

\subsection{Lessons learnt from the privatisation project}

Two critical lessons emerge from Botswana'a attempt at privatisation: (i) the need to market privatisation; and (ii) the need to delineate the legal-institutional framework so that the roles of the Executive and Legislative arms of the government in regard to privatisation are clear. It is apparent from the few case studies discussed previously that PEEPA is yet to successfully market privatisation to Botswana. As it is, most of the opposition to privatisation is borne out of fear, suspicion and lack of understanding of it as amply evidenced by some villagers branding it "a Gaborone thing" [something for urbanites].

Lastly, the Air Botswana imbroglio has clearly demonstrated the fact that there are some gray hair areas in terms of the roles of the Executive and Legislative arms of the government in regard to privatisation. On the one hand, the Executive, particularly the Cabinet, is wedded to the belief that it has full powers to implement privatisation without reference to Parliament. On the other, Parliament believes it is the custodian proper of public assets such as Air Botswana. Matters were not helped by the fact both that the Attorney General and Parliamentary Counsel gave conflicting advices on the extent of the pair's powers. Since the government has agreed to privatise the National Development Bank and is yet to privatise same during the course of the year, there is no denying the possibility that the exercise could be stalled if and when two arms of the government fight over the how to privatise the Bank.

\section{Way Forward}

Despite the aborted privatisation of Air Botswana in mid 2007, the government is still wedded to the idea of privatisation. In this regard, when delivering the Budget Speech to Parliament on 7 February 2011, the Minister of Finance of Development Planning, Kenneth Matambo, stated that in pursuit of Privatisation Policy of 2000, the government approved the privatisation of Botswana Telecommunications Corporation by committing to sell up to 49 
percent of its shares to Batswana through an Initial Public Offering [IPO] (Matambo, 2011). In addition, he stated that the "government has already undertaken to privatise the National Development Bank (NDB)" and that "my Ministry is currently working on a privatisation strategy for Cabinet's consideration and approval during the first quarter of 2011 (ibid:12)." Thus, after the Cabinet had considered the proposed privatisation of the Bank, a decision was taken to privatise it in March 2011 (Letsebe, 2011). The details are yet to be worked but, at least, the Bank will be guinea pig as far as privatisation is concerned in Botswana. Instructively, when announcing the privatisation of the Bank, Matambo stated that "NDB was established through an act of parliament and that all necessary procedures will be followed before any action is taken on the matter (ibid)." Thus, it is imperative that the executive arm of the government is not seen to be undermining the authority of Parliament as undoubtedly happened with the aborted privatisation of Air Botswana. In this regard, and as correctly pointed out by Matambo, the act that created the Bank is a creature of Parliament, therefore, it is in order that all procedures, including the final unbundling of the Bank must be sanctioned by Parliament. Beyond Parliament, the Public Enterprise Evaluation and Privatisation Agency (PEEPA) must be transparent in regard to the privatisation of the Bank.

In addition, when delivering the Budget Speech, Matambo stated that "the Government has decided to centralise the responsibility for the implementation of the privatisation programme under the Public Enterprise Evaluation and Privatisation Agency (PEEPA)" and that "PEEPA has commenced work on the review of the 2005 Privatisation Master Plan, and a report is expected before end of March 2011 (Matambo, 2011:9)." While one may appreciate this effort, there is, nonetheless, a need to re-look at the mandate of PEEPA. As it is, besides generalities, it is not clear what its mandate is; particularly, its relationship with the Cabinet. In this connection, in December 2007, then PEEPA chief, Joshua Galeforolwe, likened PEEPA to a relay runner and stated that "PEEPA finds itself in a situation of a relay race runner where one is tasked with running the first leg of the race and then pass on the baton to the next runner (Mmegi, 2007:B1)." Since one could not be sure that the next runner would run as fast as the first runner, Galeforolwe argued that there be institutional and legal reforms to ensure a smooth implementation of privatisation. Hence, at the end of the day, its mandate must be clearly defined, and to paraphrase Winston Churchill, it should be given adequate tools to finish the job [relay] to be fairly judged for both successes and failures.

At the same time, the Privatisation Policy for Botswana must be elevated to an Act of Parliament (for example, Zambia has one; the Privatisation Act was passed in 1992). In this regard, an Act of Parliament enjoys more legitimacy and protection from unnecessary transgressions. Very importantly, the envisaged Botswana Privatisation Act will clearly spell out the roles of both the executive arms of the government in regard to privatisation.

Importantly, PEEPA must enjoy some operational autonomy from the Cabinet as opposed to a case whereby the body is subjected to all manner of political football. To illustrate, in mid 2006, mainly due to the Cabinet's machinations, then PEEPA chief, Joshua Galeforolwe, was re-hired today, fired the next day and re-hired again (see Sunday Standard, 2006).

Lastly, PEEPA must regard public education as a process, not an end in itself. In this regard, 


\section{Mll Macrothink}

Research in Applied Economics

ISSN 1948-5433

2012, Vol. 4, No. 1

PEEPA must continually educate all stakeholders on the benefits and costs of privatisation rather than monomaniacally extolling the virtues of privatisation. Thus, there must be honesty, openness and transparency in explaining privatisation to the public in line with the principles of the Privatisation Policy for Botswana. In this regard, the Policy asserts that the sine qua non of a successful privatisation scheme is the explanation of potential benefits and costs to all stakeholders. The foregoing is a good policy pronouncement but experience on the ground is far from satisfactory because, to date, some stakeholders do not understand the essence of privatisation. As it is, there seems to be too much pre-occupation with extolling the virtues of privatisation, particularly efficiency gains, to the neglect of everything else. The danger though is that a monomaniacal obsession with efficiency could be pathological and may present it as the Alpha and Omega of efficient public management. This is not true because as much as efficiency is a necessary condition, it not a sufficient condition for good public management. In this connection, Fay (1976:50) fittingly poses the question; "efficient in terms of what - monetary cost, human labor? Suffering?" Thus, as much as efficiency should not be eschewed in the quest to run government efficiently (see Weber, 1947; Taylor, 1918) and like a business (see Gore, 2003), it should become an alternate religion. In this regard, Cooper (1984:147) is instructive; "technical expertise, rational approaches to problem solving, and specialized knowledge are not eschewed, but they must not provide the norms for the professional identity of the public administrator." Thus, it is incumbent upon PEEPA to move beyond its fixation on efficiency gains of privatisation and sell privatisation by explaining both the pros and cons of privatisation in equal measure. At the same time, it must demonstrate synergies between privatisation and citizen economic empowerment.

\section{Conclusion}

It is apparent that privatisation is on an irreversible march as instanced by its adoption as a public policy all over world. At the same time, the just-ended global economic downturn means that governments, particularly in the developing world, are had pressed for money and, therefore, load-shedding in the form of privatisation is inevitable. Therefore, given the fact that privatisation is here to stay, it would be preposterous for one to advocate that Botswana swim against the current. After promulgating the Privatisation for Botswana in 2000, the government tried but failed to privatise Air Botswana in mid 2007. It is sufficiently apparent from the Air Botswana imbroglio that key firsts, being the delimitation of a legal-institutional environment and public education, either did not happen first, or sloppily happened. In regard to the legal-institutional environment, it must be clear who, between the Cabinet and Parliament, is responsible for what in regard to privatisation. In addition, PEEPA's mandate is yet to be clearly spelled out and the Privatisation Master Plan needs to be re-worked and be a product of popular deliberation. In regard to public education, while it is undeniable that PEEPA has done its fair share of bringing stakeholders on board through workshops and seminars, largely, there is an emphasis on the efficiency gains of privatisation to the exclusion of almost everything else. In this regard, a balance must be struck to sell both pros and cons of privatisation and every doubting Thomas must be bought over. To end, with some of the opponents of privatisation, for example Nobel Prize laureate George Stiglitz, asserting that wholesale privatisation is not a panacea to economic ills that afflict developing 
countries, perhaps Botswana needs to approach privatisation with extreme caution. In this regard, she can learn very valuable lessons from the Chinese economic reform. China, unlike other developing nations, has demonstrated that economic reform can be achieved without massive privatisation. However, this is not to assert that the Chinese privatisation model is wholly transferable to Botswana as if it was an embryo transplant.

\section{References}

Acemoglu, D., Johnson, S., \& Robinson, J.A. (2001). How Botswana did it; comparative development in Sub-Saharan Africa. [Online] Available: http://www. Afdb.org/fileadmin/uploads/jai/Course-Materials/03...cd-4.pdf retrieved on 18 May 2010.

Baputaki, C. (2007). BTC privatisation drive on course - Venson-Moitoi. Mmegi, 16 March, p.1.

Bayford, D. (2007). Molokomme is wrong. Mmegi, 27 April, pp.4.

Becker, C. (1988). With Whose Hands: Privatization, Public Employment, Democracy. Yale Law and Policy Review, 6(1), 88-108.

BOCCIM (Botswana Confederation of Commerce Industry and Manpower). (1996). Privatisation in Botswana: August 1996 Final Report. Gaborone: BOCCIM.

BOPA (Botswana Press Agency). (2004). Moshupa residents apprehensive about privatisation. Daily News, 23 June, pp.2.

Cleary, S. (1989). Structural Adjustment in Africa. Trocaire Development Review, Dublin, Retrieved

from http://www.trocaire.org/sites/trocaire/files/pdfs/tdr/DR1989_StructuraladjustmentsinAfrica.p df retrieved on 29 August 2009.

Cooper, T.L. (1984). Citizenship and Professionalism in Public Administration. Public Administration Review, 44, Special Issue, 143-151. http://dx.doi.org/10.2307/975554

Direng, N. (2009). NDB ripe for privatization- Tibone. Mmegi, 18 December, pp. 1.

Edge, W. A. (1998). Botswana; a developmental state? In W. A. Edge \& M. Lekorwe (Eds.), Botswana: Politics and Society. Pretoria: JL van Schaik, pp. 333-348.

Fay, B. (1976). Social Theory and Political Practice. New York: Holmes and Meier.

Gore, A. (1993). From Red Tape to Results: creating a government that works better and costs less. Washington, D.C.: Office of the Vice President.

Graham, C. (2003). Methods of privatisation. In D. Parker \& S.D. Saal (Eds.), International Handbook on Privatization. Cheltenham: Edward Elgar Publishing Ltd., pp.87 -101.

IRIN. (2003). ZAMBIA: IMF urged to understand privatisation concerns. IRIN, 11 February. Retrieved from http://www.IRINnews.org retrieved on 1 April 2009.

Kahn, A., and Kamerman, S. (1989). Privatization and the Welfare State. Princeton: 
Princeton University Press.

Kangwa. S. (2001). Report on the privatization of Zambia Consolidated Copper Mines. Retrieved from http://pubs.iied.org/pdfs/G02454.pdf retrieved on 23 March 2009.

Kosar, K.R. (2006). Privatization and the Federal Government: an introduction. Retrieved from http://www.fas.org/sgp/crs/misc/RL33777.pdf retrieved on 30 September 2009.

Lekalake, L. (2007). The Attorney General is wrong; a second legal opinion. Sunday Standard, 11 June, pp.7.

Letsebe, T. (2011). Govt privatises NDB. Daily News, 10 March, pp. 10.

Madumbi, R. (2003). Introduction; globalization and the advance of markets: twin forces shaping the world economy. In R. Madumbi (Ed.), Privatization and globalization; the changing role of the state in business. Cheltenham, UK: Edward Elgar Publishing Ltd, pp. xiii-xix.

Matambo, K. (2011). 2011 Budget Speech delivered to the National Assembly on 7 February 2011. Gaborone: Government Printing and Publishing Services.

Means, H. (2001). Money and Power. New York: John Wiley and Sons.

Meggison, W.L., \& Netter, J.M. (2003). History and methods of privatization. In D. Parker \& and S.D. Saal (Eds.), International Handbook on Privatization. Cheltenham, UK: Edward Elgar Publishing Ltd., p.60 -86.

Middleton, R. (1996). Government versus the market. Cheltenham, UK and Brookefield, USA: Edward Elger.

Mmegi. (2004). GCC's Iron Lady. Mmegi, 4 February, pp.4.

Mmegi. (2006). Govt approves AB privatisation talks with SA Airlink. Mmegi, 19 December, pp1.

Mmegi. (2007). Harmonise privatisation policy with law - Galeforolwe. Mmegi, 11 December, B1.

Modise, O. (2007). Bayford offers to lead legal battle. Mmegi, 2 May, pp.1.

Mogae, F.G. (1996). 1996 Budget Speech delivered to the National Assembly on 12 February 1996. Gaborone: Government Printer.

Molaodi, P. (2004). PEEPA, NGOs disagree on privatization. Mmegi, 1 August, pp.1.

Mooketsi, L. (2007). BCP threatens to sue govt over AB. Mmegi, 30 April, pp.1.

Mosinyi, W. (2009). Stakeholders Consult on Privatisation of NDB. Mmegi, 22 June, pp. 1.

Mothusi, B., \& Dipholo, K. B. (2008). Privatisation in Botswana: the demise of a developmental state? Public Administration and Development, 28(3), 239-249. http://dx.doi.org/10.1002/pad.491 


\section{I Macrothink}

Motlogelwa, T. (2007). Winding Down AB; in their own words. Mmegi, 13 April, pp.1.

Osborne, D. with Plastrik, P. (1997). Banishing Bureaucracy. Reading: Addison-Wesley.

Osborne, D., \& Gaebler, T. (1992). Reinventing Government. Addison-Wesley, Reading.

PEEPA (Public Enterprises Evaluation \& Privatisation Agency). (2009). About PEEPA. Retrieved from http://www.peepa.co.bw/aboutpeepa.html retrieved on 1 April 2009.

PEEPA. (2004). BOSETE seeks advice on privatisation. Retrieved from http://www.peepa.co.bw/1sep2004_mediareleases.html Retrieved on 1 September 2010.

Piet, B. (2009). New Twist in Air Botswana Privatisation Mess. Mmegi, 10 April, pp.1.

Ress, M.A., \& Love, J. (1995). What is Privatization? Retrieved from http://www.essential.org/appraising/eiap/define.html retrieved on 1 April 2011.

ROB (Republic of Botswana). (1997). The Task Force on Privatisation. Gaborone: Government Printer.

ROB. (2000). Privatisation Policy for Botswana (2000). Gaborone: Ministry of Finance and Development Planning.

Savas, E.S. (1987). Privatization: the key to better government. New Jersey: Chatham.

Sheshinski, E., \& López-Calva, L.F. (2003). Privatization and Its Benefits: Theory and Evidence. CESifo Economic Studies, 49(3), 429-459. http://dx.doi.org/10.1093/cesifo/49.3.429

Smith, A. (1776). An Inquiry into the Nature and Causes of the Wealth of Nations. Oxford: Oxford University Press.

Sobel, R. (1999). The pursuit of wealth. New York: McGraw-Hill.

Starr, P. (1988). The Meaning of Privatization. Yale Law and Policy Review, 6(1), 6-41.

Stiglitz, J.E. (2002). Globalization and its Discontents. $1^{\text {st }}$ edition. Washington, DC: W. W. Norton \& Company.

Sunday Standard. (2006). PEEPA board resigns en masse. Sunday Standard, 2 September, pp.4.

Taylor, F.W. (1988). The Principles of Scientific Management.New York: Dover.

The Voice. (2007). Legal status of Air Botswana Privatisation. The Voice, 1 May, pp.1.

Tsie, B. (1998). The state and development policy in Botswana. In K.R. Hope \& G. Somolekae (Eds.), Public Administration and Policy in Botswana. Capetown: Juta \& Co., pp. $1-20$.

Weber, M. (1946). Bureaucracy. in J.M. Shafritz and A.C. Hyde (Eds.), (1997), Classics of Public Administration (4th ed.) New York: Harcourt Brace College Publishers, pp. 37-43 


\section{Macrothink}

Weizsacker, E.U., Young, O.R., and Finger, M. (2005). Limits to privatization. In E.U. Weizsacker, O.R. Young \& M. Finger (Eds.), Limits to privatization; how to avoid too much of a good thing. London: Earthscan, p.3-14.

Willner, J. (2003). Privatization; a sceptical analysis. In D. Parker \& S.D. Saal (Eds.), International Handbook on Privatization. Cheltenham: Edward Elgar Publishing Ltd., p.60 $-86$.

\section{Copyright Disclaimer}

Copyright reserved by the author(s).

This article is an open-access article distributed under the terms and conditions of the Creative Commons Attribution license (http://creativecommons.org/licenses/by/3.0/). 